\title{
DA COLÔNIA À PRIMEIRA REPÜBLICA: UM BALANÇO DAS IDÉIAS PEDAGÓGICAS NO BRASIL1
}

\author{
SILZA MARIA PAZELLO VALENTE 2
}

VALENTE, S.M.P. Da colo̊nia à primeira república: um balanço das idéias pedagógicas no Brasil. Semina: Ci. Soc/Hum., Londrina, v. 13, n. 3, p. 195-207, set. 1992.

RESUMO: $A$ análise das idéias pedagógicas, desde a Colbnia até à Primeira República, evidencia que poltica e economia se articularam no sentido de direcionar a educação. Evidencia, também, que, no universo pedagógico, surgiram propostas apontando caminhos que visavam livrar a educaçăo formal da opressấo. A pesquisa desenvolvida demonstrou que existiam dois projetos educacionais antagónicos na vigéncia da Primeira República. Um oficial, influenciado pelas idéias pedagógicas dos jesulas, $\theta$ outro proposto polos socialistas - anarquistas e comunistas -, que pretendia responder ds exigéncias de um momento histórico no qual as relaçסes de trabalho passavam por uma profunda transformaçắ. Ambos foram superados por um terceiro projeto - 0 da Escola Nova - que invadiu o espaco podagógico com um ideário importado da Europa e dos Estados Unidos, e possibifitou que uma classe que se via ameaçada - burguesia - se recompusesse e continuasse a exercer a hegemonia.

PALA VRAS-CHAVE: Educaçāo; ldéias pedagógicas; Colónia; Primeira República; Anarquistas; Comunistas

\section{1 - INTRODUÇĀO}

Julgamos não ser possível compreender o fenômeno educativo sem apreender suas ralzes históricas, sem encará-lo de maneira relacionada com os outros elementos que compōem o universo no qual está contextualizado. Dal porque nos detivemos primeiramente em pesquisar e compreender o sistema sócio-económicopolítico para, só entāo, analisarmos o educacional.

Sendo assim, o trabalho foi desenvolvido em três momentos:

19) Histórico: do Feudalismo ao Capitalismo

29) O Capitalismo no Brasil

39) Da Colónia a Primeira República: balanço das idéias pedagógicas

Procuramos retirar o vêu que encobria o ideário pedagógico do Movimento Operário na Primeira República, assim como desvendar os reais propósitos do projeto pedagógico oficial.

Esperamos que aquilo que foi trazido às claras possa, de alguma maneira, contribuir para a compreensão do nosso cotidiano educacional.

\section{2 - HISTÓRICO: DO FEUdALISMO AO CAPITA- LISMO}

A história da humanidade demonstra que o poder muda de mảos, que classes 3 originariamente negligenciadas, vāo se fortalecendo e acabam por assumir o controle económico e polftico da sociedade.

A ascensão e o fortalecimento de uma determinada classe dependem nāo sớ da capacidade de organizaçăo da classe em si, mas também da concepção de mundo e de homem que imprimem a caracteristica da época.

Assim \& que, à medida em que a terra näo mais foi concebida como estática e centro do universo, como durante as Idades Antiga e Média, também o conceito de movimento foi introduzido, na sociedade, e possibilitou a aceitaçāo de mobilidade social, de ascensăo. $O$ poder năo era mais um direito divino, mas objeto de conquista humana. A figura do rei năo era mais inquestionável, tudo era passivel de mudança, desde os mais simples hábitos até as diretrizes fundamentais da sociedade.

Com a evoluçăo da ciência, o controle exercido pela Igreja decresceu e foi aberto um espaço onde idéias vi-

1 - Trabalho realizado para a Disciplina História das Idéias Pedagógiçss no Brasil, ministrada pelo Prof. Dr. Dermeval Saviani - Mestrado em Educaçáo - UNICAMP.

2 - Profa. do Departamento de Educaçáo - CECA/Universidade Estadual de Londrina, Caixa Postal 6001, Londrina, Paraná, Brasil, CEP $86051-970$

3 - Utillzo o termo classes baseando-me em MARX \& ENGELS (1988, p. 68) que, no Manifesto Comunista afirmam: "a história de tode sociedade até hoje s a história de lutas de classes", mas com um certo constrangimento por considerer, a exemplo de THOMPSON (1979), que a categoria clasee so \& adequade para as sociedades industrializades. Nas sociedades pro-industriais as pessoas se consideravam en termos de estados, hierarquias, ordens, etc. 
cejaram toda a estrutura que sustentava um mundo estático, foi sacudido com um Impeto arrebatador.

O resultado dessa força incontrolável foi a derrocada do feudalismo e a implantaçåo do capitalismo.

É evidente que as condiçōes que possibilitaram o capitalismo não surgiram da noite para o dia.

Foi toda uma mudança dos modos de produçāo e das relaçōes sociais que forneceu as condiçóes para que a economia se transformasse em um outro sistema.

LEO HUBERMAN (1985), descreve brilhantemente a passagem do Feudalismo ao Capitalismo demonstrando como se processavam as relaçōes económicas durante a Idade Média: como os servos e camponeses eram explorados pelos senhores feudais em troca de proteção; como as cruzadas, que pretendiam ter cunho religioso, no fundo se constitulam em interesses comerciais para o enriquecimento dos reis, da burguesia e da Igreja; como o aumento do comércio possibilitou o crescimento das

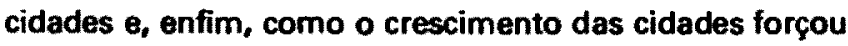
a mudança das relaçס̄es sociais atê entāo vigentes.

Segundo o autor,

"nos primordios do feudalismo, a terra, sozinha, constitula a medida da riqueza do homem. Com a expansáo do comércio surgiu um novo tipo de riqueza - a riqueza em dinheiro. no infcio da era feudal, os sacerdotes e guerreiros, proprietários de terras, se achavam num dos extremos da escala social, vivendo dos trabalhos dos servos, que se encontravam no outro extremo. Agora, um novo grupo surgia - a classe modia, vivendo de uma forma nova, da compra e venda. No perído feudal, a posse da terra, a única fonte de riqueza, implicava o poder de govemar para o clero e a nobreza Agora, a posse do dinheiro, uma nova fonte de riqueza, trouxera consigo a partilha no govemo, para a nascente classe ms dia". (HUBERMAN, 1985, p. 44)

Quanto à classe trabalhadora, devia somente servir ao parașitismo da nobreza e do clero, pagando os impostos, produzindo os grăos, defendendo os domínios em caso de guerra e vivendo na mais deprimente misêria.

No feudalismo, a economia era de consumo, cada aldeamento produzia praticamente o necessário para sua subsistência; quando havia necessidade de intercâmbio, este era feito atravês da troca de mercadorias. Quase não havia produçāo de excedentes, o comércio era local devido ao péssimo estado das estradas, o dinheiro era escasso e a moeda nāo era padronizada.

No século $X \mathrm{I}$, osse panorama principiou a mudar: as cruzadas passaram a trazer novas e interessantes mercadorias que incrementaram o comércio, atraves do interesse despertado para a aquisiçăo dos produtos atê entāo inexistentes no mercado. Além disso, houve uma mudança nas exigéncias dos consumidores o que propi- ciou o surgimento dos artessos que passaram a viver nos burgos (cidades fortificadas) o se dedicar a manufatura dos produtos exigidos pelos consumidores. ?

O movimento das feiras aumentou, a produção que antes tinha apenas o valor de uso transformou-se em mercadoria e passou a ter também o valor de troca ${ }^{4} e_{\text {, }}$ para facilitar a troca, intensificou-se o uso do dinheiro. $A$ economia que, no inlcio da Idade Média, era auto-suficiente e baseada na permuta de mercadorias transformou-se em uma economia baseada na moeda, refletindo a expansāo do comércio.

O aumento da população dos burgos, o surgimento dos artesāos e sua uniāo em corporaçōes, o enriquecimento de uma parcela da populaçăo, devido ao comércio, fez com que reivindicaçōes surgissem, alterando as caracterlsticas de vida da época. A liberdade de ir e vir e de compra e venda, a diminuição das barreiras alfandegárias, a possibilidade do empréstimo de dinheiro a juros (que antes era terminantemente proibido pela Igreja), sâo alguns dos elementos que precisaram ser alterados para atender a nova realidade social.

Surge, neste momento histórico, a separaçăo do trabalho entre cidade e campo e, pela necessidade de maior produçăo agrícola, a cobiça pelas terras inexploradas.

Como resultado da pressāo das novas necessidades geradas pela circulação da moeda, a terra, que antes era privilégio de nobres e clérigos, passou a ser comprada, vendida $e$ trocada livremente.

O campones entrevia a possibilidade de ascenşo $\theta$ passava a se interessar por novas formas de trabalho; ele que, antes, era fadado a nascer e morrer na mesma situaçăo.

Uma tempestade de idéias varria a Europa e mudava a face do Velho Continente. Atê a Idade Média nảo havia naçōes, mas cidades; com o fortalecimento da classe média, essa estrutura geo-polftica mudou. Interessava aos novos-ricos, aos cidadāos, enfraquecer o poder dos senhores feudais e, para isto, fortaleceram economicamente o rei que, até entāo, era uma figura frágil.

Essa modíficaçāo processou-se lentamente, mas, no decorrer do seculo XV, começaram a surgir as naçōes e as regulamentaçōes, que eram locais, passaram a ser regionais.

$\mathrm{Na}$ medida em que os burgueses fortaleciam os reis, esses os favoreciam através de leis que desprestigiavam os senhores feudais.

Essa foi a época da Revoluçăo Comercial (do séc. XIII em diante), em que Portugal, Espanha, Holanda, Inglaterra e França se lançaram aos mares procurando ansiosamente novas fontes de produtos e novos mercados.

Era o deus Lucro a orientar as açঠes mercantilistas.

A par com o Capitalismo Comercial, surgiu o Capitalismo Financeiro que teve como causas os progressos

A - Para MARX (1980), o valor de troca des mercadorias esté baseado na força de trabalho do homem e se mede pelo tempo modio de fórce de trabalho que leva a prodicho de mercadories. As troces säo realizadas por meio de uma outra mencadoria de valor equîvalente. Nas sociedades modernas, 0 dinheiro intermedia a troca. 
do crédito público, o cámbio (devido à diversidade das moedas), o desenvolvimento dos bancos $\mathrm{e}$, consequentemente, 0 afluxo de mercadorias e de metais preciosos advindos das conquistas marltimas.

Através das atividades no comércio e das especulacōes financeiras, a burguesia enriqueceu.

Os burgueses tinham o poder económico, o Capita ${ }^{5}$, mas năo tinham o poder polftico.

Os reis, financiados pelos burgueses, se fortaleciam e exploravam a população a fim de cobrirem as mais escabrosas despesas. $O$ Estado sugava incansavelmente todos os recursos disponiveis.

A burguesia financiava os desmandos, mas nāo se via reconhecida como co-participe do poder ou das regalias. Essa situação tornou-se irritante e humilhante; na França, principalmente, a situação tornou-se politicamente insustentável.

O povo - Terceiro Estado - que constitula $95 \%$ de uma população de 26 milhōes de habitantes (sendo que 22 milhöes eram camponeses) revoltou-se sob a lideranca da burguesia, tomou o poder e instituiu uma nova o:dem sócio-politico-económica baseada nos principios do Liberalismo Clássico, cuja expressäo maior é o capitalismo.

São esses os principios do Liberalismo Clássico: liberdade (intelectual, religiosa, polftica, económica): igualdade (perante à lei); direito natural à propriedade; individualismo e democracia como forma de governo.

A Revolução Francesa completou 200 anos, em 1989, e algumas reflexōes a respeito desse acontecimento, pela influéncia que exerceu no resto do mundo e pelo novo rumo que deu à humanidade, são necessárias.

É importante frisar aqui que, embora tendo tomado parte ativa na derrocada do velho regime, o povo foi utilizado pela burguesia como massa de manobra e alijado do poder.

- MARX (1987, p. 11-12), em "As Lutas de Classes" afirma a respeito da alta burguesia francesa: "Ela reinava, ela ditava as leis às Câmaras, distribula os cargos públicos, desde os ministérios até as tabacarias" $e$, comentando a exclusão das outras classes, no poder "a pequena burguesia em todas as suas nuances e a classe camponesa estavam completamente excluldas do poder politico".

Por essas afirmaçōes percebe-se como os detentores do Capital envolveram os camponeses e a pequena burguesia com um 'discurso eloquente, com promessas de igualdade $\theta$ fraternidade. Discurso de total incoeréncia com a situação posterior, pois a alta burguesia, primeiro a financeira depois a industrial, os deixou de lado e se adonou do poder. Sugou incansavelmente a capacidade produtiva do trabalhador, na busca constante do lucro, deixando um rastro de naçōes e pessoas miseráveis. Um novo deus passou a ser incensado, 0 deus Capital, que só pretendia uma oferenda no altar dos sacriffcios: o trabaIhador.

O Capitalismo Comercial e o Financeiro propiciaram a introdução da máquina no processo produtivo e os progressos técnico e cientlfico. $O$ artesão já não podia suprir as necessidades do mercado. Sua produçāo era por demais escassa e seus instrumentos de trabalho ineficientes; sua força de trabalho, ao contrário, era indispensável.

Sendo assim, o trabalhador viu-se expropriado do seu instrumental $e$, ao invés de vender o produto do seu trabalho, passou a vender a sua própria força vital.

Alêm do artesão, expropriado do seu instrumento de trabalho, havia tamberm as pessoas expulsas das terras devido ao cercamente de propriedades que antes eram abertas ao uso da comunidade.

A privatização dessas terras fez com que um grande número de camponeses passasse a perambular em busca de ocupação e se transformasse em um exército de mãode-obra disponivel, pronta para ser aproveitada nas fábricas.

HUBERMAN (1985, p. 174) afirma que os trabalhadores só se sujeitam a trabalhar para outrem quando sāo expropriados do seu meio de produção, seja ele a terra ou a ferramenta. Sendo assim, "a história da criação de uma oferta necessária à produção capitalista deve... ser a história de como os trabalhadores foram privados dos meios de produçāo" e, citando MARX, "...a história disso, de sua expropriaçāo é escrita nos anais da humanidade em letras de sangue e fogo".

Através da introduçăo da máquina no processo produtivo do incremento da técnica, iniciou-se, na Inglaterra ${ }^{6}$, a Revoluçāo Industrial, que forneceu a base material de nossa época.

A par com a Revolução Industrial, também sucederam a Revolução Agricola e a dos Transportes. A Revolução da Agricultura diretamente ligada à aplicação do capital no campo, que teria sido impossivel no sistema antigo de campos abertos e a Revolução dos Transportes diretamente ligada às outras duas devido à necessidade de escoamento da produçāo.

Mas năo foi só o progresso que chegou com a implantaçāo do Capitalismo; com o novo sistema econômico veio também a exploração do homem pelo homem e das naçס̄es mais pobres pelas mais desenvolvidas.

Um novo mundo nasceu sob a batuta da classe burguesa.

"Onde quer que tenha chegado ao poder, a burguesia destruiu todas as relaçós feudais, patriarcais, idficas. Dilacerou impiedosamente os variegados laços teudais que ligavam o ser humano a seus superiores naturais, e năo deixou

5 - "O dinheiro só se toma capital quando \& usado para adquirir mercadorias ou trabalho com a finalidade de vende-los novamente, com lucro". (HUBERMAN, 1985, p. 167 )

6 - ENGELS em nota de rodape à ediç̃o inglesa do Manifesto Comunista, afirma que o Manifesto toma a Franca como pais tlpico do desenvolvimento polfico a inglaterra como pais tipico do desenvolvimento económico da burguesia. (MARX \& ENGELS, 1988) 
subsistir entre homem e homem outro vfnculo que náo o interesse nu e cru, o insensivel pagamento em dinheiro". (MARX \& ENGELS, 1988, p. 68)

Desde a sua implantaçāo atê o presente momento, - Capitalismo passou por transformaçōes que demons. tram sua preocupação em mudar para permanecer.

À medida em que a insatisfação social foi crescendo e pressionando o capital com a ameaça da diminuiçāo dos lucros, o sistema foi se transmutando e procurando se adaptar à nova realidade emergente, foi se fortalecendo.

Um sistema econômico que nasceu sob a égide das livres iniciativa e concorrência e amparado por um Estado nāo intervencionista, \& hoje caracterizado por elementos não presentes quando de sua implantação.

A explicação para esta mudança de atitude do capitalismo talvez esteja nas inúmeras lutas desencadeadas pelos trabalhadores em prol da conquista do seu espaço na sociedade.

Lutas estas que convulsionaram a Europa do final do século passado e inlcio do século atual, influenciadas pelo socialismo utópico (anarquismo) e pelo socialismo do partido comunista.

A sociedade brasileira sentiu os reflexos dessa crise mundial, haja vista as greves operárias que ocorreram em várias cidades brasileiras (principalmente em São Paulo e no Rio de Janeiro) durante os primeiros trinta anos deste século, influenciadas e lideradas pelos anarquistas.

O capitalismo percebeu que era autofágico: estava criando no seu ventre o monstro que iria devorá-lo. A classe operária tâo necessária para alimentá-lo, era constitulda de uma populaçāo que crescia dia a dia, tanto numericamente quanto em conscientizaçăo, que se organizava e que havia demonstrado capacidade para assumir 0 controle de uma naçāo - Rússia -. Era necessário mudar os meios, preservando, evidentemente, o fim: o lucro.

Para explicar a estrutura da sociedade civil, buscando compreender os motivos que levam os homens a proceder de determinada maneira, Marx e Engels utilizaram a metáfora do edificio base (infra-estrutura) e superestrutura. A infra-estrutura refere-se às relaçōes económicas que condicionam a superestrutura: organizaçāo polttica, movimentos sociais, educaçăo, cultura, religiāo; assim como a ideologia de uma classe.

Esta formulação poderia gerar o entendimento mecanicista da relação entre infra e superestrutura e Marx teve plena consciência desta possibilidade, tanto que fez um alerta contra o reducionismo económico a que poderia levar uma interpretação inadequada. "É por isto que ele caracterizou essa relação como histórica, desigual e compativel com a eficócia própria da superestrutura" (DICIONARIO DO PENSAMENTO MARXISTA, 1988, p. 27), o que nos leva a inferir que há uma relaçăo díalética entre o económico e o politico. Săo forças que se inter- penetram, se influenciam mutuamente e possibilitam mudanças reciprocas.

A compreensâo da estrutura do capitalismo, na época atual, passa por esta via. A pressäo do operariado mudou a visăo de mundo dos capitalistas levando a ideologia neoliberal; esta, por sua vez interferiu no económico mudando as relaçōes que ocorriam na base.

Embora a relaçāo de exploraçāo permaneça, ela ê amenizada pelas conquistas sociais que possibilitam ao trabalhador melhores condiçôes de trabalho e pretendem encobrir o conflito de classes.

COVRE (1982), entende a ideologia neocapitalista, como formada por um conjunto de doutrinas que ajudam a compor a nova ideologia burguesa ou o pós-liberalismo. Estas doutrinas procuram explicar as transformaçöes que deram origem à sociedade capitalista, a partir de um ponto de vista nāo marxista, obscurecendo a luta de classes e apresentando uma concep̧ão idealista do Estado. da intervençäo pública e do planejamento.

A autora aponta como caracteristicas da ideologia neocapitalista: a ascençāo do Estado intervencionista, a influência da burocracia e o desenvolvimento da tecnologia com consequente valorizaçāo da figura do técnico.

Esta terceira fase do Capitalismo, a Monopolista las duas anteriores foram a Mercantilista, onde o monopólio era do Estado e a Liberal Clássica, baseada nas livres iniciativa e concorréncia, como já foi frisado), se constitui no avanço do capitalismo internacional.

Săo caracteristicas do monopolismo:

19) concentraçăo do capital nas mãos de um menor número de proprietários: constituiçāo de cartêis;

29) separaçăo entre propriedade e controle:

39) desenvolvimento das ciências possibilitando a introduçāo da tecnologia no espaço fabril, com consequente aumento da produtividade e do lucro;

4\%) criaçăo de um quadro técnico altamente capacitado para o gerenciamento das empresas (burocratas e tecnocratas);

59) racionalizaçāo das açס̄es para obter maior eficiência;

6ㅇ imperialismo económico para a colocaçāo da superproduçäo;

$\left.7^{9}\right)$ fortalecimento do Estado, já que este precisa atuar em todos os setores e tomar atitudes socializantes a fim de se preservar;

89) necessidade de uma máquina burocrática estatal para gerenciar os recursos. Recursos esses que sảo cada vez mais escassos;

99) tecnologia gerando necessidede de especializaçāo;

109) estado intervencionista, parceiro do capital internacional do capital nacional, dando sustentaçăo e legitimaçăo ao monopolismo.

As idélas defendidas pelos teóricos do neocapitalismo levaram ao entendimento da neutralidade da ciência, da técnica e do planejamento. 
Sobre este pressuposto de neutralidade, erigiu-se um altar ao Capitalismo. Nâo se percebeu, ou não se quis perceber, que toda ciência, técnica ou planejamento corresponde a uma visảo de mundo - ideologia - e que, por isto mesmo, está comprometida com a classe que tem o poder nas mảos.

GORZ (1979, p. 81), afirma que até princlpios de 1960, os marxistas também cometiam este erro de avalia. ção, pois "consideravam as forças produtivas - em particular as ciências e a técnica - como ideologicamente neutras e seu desenvolvimento como intrinsecamente positivo".

\section{3 - O CAPITALISMO NO BRASIL}

O Brasil foi descoberto em um momento histórico no qual o capital comercial se expandia avidamente buscando, com ansiedade, obter lucros cada vez maiores. Era a burguesia que procurava se consolidar como classe detentora do poder económico e, para conseguir seu intento, lançava mão de todos os meios.

Esse furor em busca do lucro näo media sacriff́cios, não tinha limites, não hesitava em dilapidar, vilipendiar, explorar às últimas consequências as novas terras descobertas.

A história do Brasil é uma história onde essa exploração estố presente em todas as suas configuraçōes: metrópole/colónia; colonizador/colonizado; proprietário/escravo; patrăo/assalariado.

Interessa-nos, nesse capltulo, procurar entender os determinantes polfticos e económicos que nortearam a implantação do capitalismo no Brasil.

Bastante rica nos pareceu a análise feita por MELLO (1988) a respeito do desenvolvimento económico brasileiro. Buscou o autor, nesta análise, duas perspectivas: a interna e a externa. Condiçōes históricas particulares, peculiares do pais em questäo e condiçōes macro-estruturais que são fatores de influéncia, mas não suficientes para condicionar de maneira absoluta o direcionamento evolutivo de uma dada economia.

O autor procura explicar a implantação de um capitalismo tardio, partindo da proposta de uma periodização onde o momento anterior contém os germes do próximo; onde elementos antagónicos se interpenetram, se interinfluenciam e produzem um novo sistema, fruto de um aparente, mas so aparente antagonismo. Antagonismo mais de forma que de essência.

Esta periodizaçāo: Economia Colonial, Economia Mercantil - escravista cafeeira colonial -, e Economia Exportadora (retardarária nas suas 3 fases: nascimento e consolidação da grande indústria, industrialização restringida e industrializaçäo pesada) permite que se repense a história latino-americana sob um outro ángulo: "como formação e desenvolvimento do modo de produção capitalista". (MELLO, 1988, p. 27)

Sob um ponto de vista ortodoxo, ficaria diffcil caracterizar a Economia Colonial Escravista como capitalista, jấ que nela năo está presente a categoria salário como fato explicativo da exploraçāo do trabalho pelo capital. Contudo, foi buscando as peculiaridades da formaçăo económico-social brasileira que o autor afirma: "no sistema colonial de produçăo há, formalmente, capitalismo porque a escravidão é escravidäo introduzida pelo capital...". (MELLO, 1988, p. 44)

Este capitalismo, podemos afirmar, t/pico do Brasil e atrasado em relação ao estágio em que se encontrava o capitalismo europeu e norte-americano tinha sua razăo de ser: os acordos económicos entre Portugal e Inglaterra impediram que aquele desenvolvesse uma burguesia industrial.

Enquanto, no séc. XVIII, a Inglaterra passava por uma revolução que daria novos rumos à sua economia, Brasil e Portugal, metrópole e colónia, igualmente espezinhados permaneciam atrasados em relação ao que ocorria com o capitalismo dos palses mais adiantados.

Se nossa economia permanecia agrária e escravista, era porque, de certa maneira, satisfazia aos interesses do capital mercantilista que sustentava esta estrutura.

Quando, em 1889, foi proclamada a República, um ano apenas após a abolição da escravatura, foram dois sistemas que passaram por transformaçöes.

O económico, que já estava preparado para absorver a mudança e introduzir o trabalho assalariado, e o politico que instaurou a República, um sistema de governo baseado na representatividade popular, mas onde o povo parece ter sido pego de surpresa, como afirma BASBAUM (1981).

Para que a República fosse proclamada, foi necessária a uniāo de duas vertentes: uma liberal, defendendo o federalismo e o individualismo e outra positivista que defendia o centralismo e era a que influenciava o exército.

O perfodo de consolidação da República foi difícil, conturbado, repleto de embates entre estas duas correntes de pensamento, mas o corte que nos interessa aqui é aquele que aponta para o inicio efetivo da industrialização no pals e para a formaçăo de um empresariado nacional. Foi de 1888 a 1933 que nasceu e se consolidou o capital industrial. (Apenas para uma visảo do macro, cumpre enfatizar que entre 1880-1900 foi o momento de emergéncia do capital monopolista, em termos mundiaist.

Portanto, quando começamos a engatinhar no sentido de implantar o capitalismo industrial, este mesmo capitalismo, na Europa e Estados Unidos, formava cartéis e lançava seus tentáculos sobre outras regiōes do mundo se transmutando em monopolista.

Como já foi referido, MELLO analisou o desenvolvimento económico brasileiro partindo do pressuposto que o periodo anterior continha os germes do posterior. Assim, afirma ele:

* complexo exportador cafeeiro, ao acumular, gerou o capital-dinheiro que se transformou em capital industrial e criou as condiços necessárias a essa transformaçáo: uma oferta abundante no mercado de trabalho e bens de consumo e capitais..." (MELLO, 1988, p. 101) 
Deduz-se desta afirmação que burguesia agrária $e$ industrial estiveram essencialmente ligadas, já que foram os lucros agrfcolas aplicados na indústria que possibilitaram o desenvolvimento industrial brasileiro.

Foi de 1880 a 1933 que o capital industrial nasceu e se consolidou, investindo basicamente na produçāo de bens de consumo assalariado e em indústrias leves de bens de produção.

Para a implantação desta indústria (e para a exploração da terra devido à abolição da escravatura), foi necessário que um enorme contingente imigratório adentrasse as fronteiras brasileiras. Com estes imigrantes, oriundos de palses onde o processo industrial já se achava adiantado, adentraram também novas idéias, novas maneiras de se enxergar o mundo, novas reivindicaçōes que permearam a Primeira República (1889-1930) de movimentos sociais nitidamente influenciados pelas idéias anarquistas.

Foi por influência dos anarquistas que os trabalhadores fabris (na sua grande maioria estrangeiros) se organizaram e pressionaram os patrōes no sentido de obter ganhos salariais e melhoria das condiçóes de trabalho.

Continuando com a periodizaçäo de MELLO, a fase seguinte que vai de 1933 a 1955 e a da Industrialização Restringida. Nesta fase o setor industrial corta as amarras do cafeeiro. $O$ autor explica a denominação utilizada da seguinte maneira:

Industrialização - porque o vetor da acumulação agora $\mathbf{e}$ a indústria.

Restringida - porque as bases têcnicas e financeiras desta acumulação sāo insuficientes para a implantação rápida de um nứcleo de bens de produção que possibilitaria a produção crescer mais do que a demanda e determinar o processo de desenvolvimento industrial.

Neste momento o que o capital industrial exige do Estado e:

19) protecionismo contra as importaçōes:

29) arrefecimento do Impeto trabalhista, impedindo sindicatos independentes;

39) investimento em infra-estrutura que assegurasse economia às indústrias.

Como se percebe, é a solicitação para que o Estado assuma o papel de aliado e protetor da indústria. E este papel foi sendo assumido cada vez com mais intensidade.

Já nos reportamos anteriormente ao fato que, para a proclamaçăo da República, foi necessária a composição de liberais e positivistas.

Quando da sua instalaçâo, foi a corrente liberal que influenciou a formaçăo do novo governo e, com ela, o princlpio do nảo-intervencionismo estatal na economia.

A medida que a República foil se consolidando, houve uma inversäo: cada vez mais eram os principios positivistas que influenciavam as açöes governamentais.
Durante a maior parte do perlodo de Industrializa. ção Restringida Getúlio Vargas quem está no poder (1930-1945/reeleito em 1950 permanece ate 1954), um herdeiro de Júlio de Castilhos, que se incumbiu de transplantar o castilhismo do Rio Grande do Sul para o Rio de Janeiro (PAIM, 1967). Adepto do ideário positivista que pregava um governo forte e centralizado, vargas cooptou os IIderes trabalhistas imprimindo ao movimento operário a caracteristica de peleguismo ${ }^{7}$.

COVRE (1988), analisando o desenvolvimento económico brasileiro, neste mesmo perlodo, afirma que, apesar do capitalismo em termos mundiais já estar na fase monopolista, houve a proposiçăo nacionalista de desenvolvimento, o que era preciso para o grande capital emergente acelerar $o$ industrialismo.

Este processo de internacionalização do capital, baseado em um discurso nacionalista, necessário para evitar confrontos internos, continuou durante o governo de Juscelino Kubitschek (1956-1960) que, sob a bandeira do desenvolvimento, abriu as portas do pals ao capital internacional.

É durante o governo de Juscelino Kubitschek (J.K.), que MELLO situa a $3^{\text {a }}$ fase da Economia Exportadora Capitalista: a fase da Industrializaçảo Pesada (1956-1961). São suas caracteristicas:

19) mudança radical do sistema produtivo, com avanços tecnológicos;

$\left.2^{\circ}\right)$ capacidade produtiva alêm da demanda gerando um novo padráo de acumulação.

O autor (MELLO, 1988, p. 117), denomina esta fase de pesada "porque este tipo de desenvolvimento implicou um crescimento acumulado da capacidade produtiva do setor de bens de produçáo e do setor de bens duráveis de consumo antes de qualquer expansăo previsivel de seus mercados".

MELLO e COVRE se posicionam coincidentemente quanto à entrada do capital estrangeiro: consideravamno vital nesta fase, assim como a presença do Estado na expansão industrial. Sem a presença dele seria quase impossivel as empresas arcarem com os custos de implantação e modernização.

MELLO aponte o perlodo 1962-1967 como o perlodo de depressão, enquanto que o primeiro foi de expansão da fase de industrialização pesada. Aponta como causa da depressăo a queda das taxas de crescimento, já que não foi possivel sustentar a mesma taxa de acumulação verificada entre 1956 e 1961. Considera 1961 como o final do processo de industrializaçāo, jấ que doravante a autodeterminaçäo do capital está assegurada.

Consideramos importante fazer uma referência poIftico-aconómica ao perlodo pós-64 dado o seu significado para o momento atual.

Ainda uma vez retornamos às influências liberal e positivista: foi a segunda que predominou no meio miquestioná-la. Os Sindicatos Amarelos foram os precursores deste tipo de Sindicalismo. (ANTUNES, 1989) 
litar. 0 castilhismo influenciou o polltico, assim como o positivismo o meio militar 8 .

Sendo assim, durante o perfodo da ditadura militar - ideário comtiano pode ser novamente colocado em prática, já que de 1930 a 1945 um civil o utilizara. (J.K. representou um sopro de liberdade entre dois periodos ditatoriais!)

Em termos económicos, 1964 veio consolidar um propósito de longa data. O capital monopolista que adentrara o pals sob as bençāos do Estado e do empresariado nacional foi, enfim, entronizado.

Em "A Fala dos Homens", COVRE (1988) evidencia como o discurso dos intelectuais orgânicos da revoluçāo (golpe) encontrou argumentos para todas as atitudes que foram tomadas em relação à entrada do Brasil na etapa monopolista do capital.

Nele aparecern: a defesa do Estado intervencionista como a maneira correta de direcionar o desenvolvimento, atraves de um planejamento racional eficiente; $e$ do endividamento externo como necessário para o progresso e bem-estar da naçăo; a proposta de uma distribuiçăo mais justa da renda nacional a partir, naturalmente, do momento em que a acumulaçăo o permita; e a denúncia de ideologias estranhas, subversivas, que só servem para prejudicar o Brasil e os brasileiros.

Quais as consequências do capital monopolista enfim implantado em nossa pátria? Resolveu ele os males que nos afligiam? Como está hoje o Brasil?

Näo se pode negar que, impelido pelas necessidades do capital, o Brasil teve um desenvolvimento espantoso em duas décadas, principalmente nos setores de transportes, telecomunicaçōes e energético.

Já năo se pode dizer o mesmo no que tange à saúde e educação.

O que se deve perguntar é: a que preço?

Pelos dados estatisticos, o preço pago muito alto. Vejamos o que afirma HELIO JAGUARIBE (1986, p. 18):

$59 \%$ das pessoas mais pobres percebem apenas $13 \%$ da renda total do pals; $46,2 \%$ dessa renda ficam com $10 \%$ da população mais rica, sendo que $5 \%$ desses $10 \%$ percebem $33 \%$.

$O$ indice de mortalidade infantil é um dos mais altos do mundo: a cada 3 minutos morre uma criança.

$O$ indice de analfabetismo ê de $47 \%$ no nordeste $18 \%$ na regizo sul-sudeste.

Segundo o Secretário do Ensino Básico do Ministério da Educaçăo, José Raimundo de Carvalho, a situaçăo ê bastante grave (ele apresenta dados ainda mais assustadores que JAGUARIBE): "somos 50 milhōes de analfabetos no pals, o que nos dá $42 \%$ da populaçāo residente com mais de cinco anos. Estamos em estado pior que o Congo (37\%) e em pé de igualdade com Zimbábul (45\%). (apud PRADO, 1988, Cad.A, p. 8)

Este é o retrado de um pals, considerado como possuidor da $8^{\text {a }}$ economia do mundo, onde cerca de
$61,2 \%$ da populaçăo vive em estado de pobreza ou misê. ria.

\section{4 - DA COLÓNIA A PRIMEIRA REPÚBLICA: BA- LANÇO DAS IDÉIAS PEDAGÓGICAS}

Nos momentos anteriores procuramos demonstrar a necessidade de se compreender a educação como um elemento interagindo com os outros que compōem o sistema social, evitando-se o reducionismo de considerála capaz de superar-se a si mesma, desligada do todo que a explica, justifica, cerceia, mas no interior do qual ela procura os caminhos de sua superação.

Essa análise crftica, é uma anślise que necessita captar as condiçōes históricas nas quais as idéias pedagógicas se originaram e, pelo que já foi exposto, ficou evidenciado que essas idéias repousam na base material que Ihes dá sustentação. No entanto, como o próprio MARX (MARX \& ENGELS, 1986) adverte, na sua III tese sobre Feuerbach: se os homens sāo frutos das circunstâncias, atravếs das suas idêias, são capazes de alterá-las.

Quando o Brasil foi descoberto, a ordem feudal estava em derrocada e o capitalismo em plena articulação. Portugal se enquadrava perfeitamente no capitalismo comercial como ponta de lança ds grandes navegaçōes e descobertas.

Internamente, no entanto, na nação portuguesa, se digladiavam a velha e a nova ordem. $E$ a velha ordem, representada pelas idélias reacionárias, conseguiu impor sua visão de mundo através da contra-reforma, onde se revitalizaram valores que estavam sendo superados.

Essa imposição, ou melhor dizendo, esse ganho de causa das idéias da velha ordem, fez com que o capitalismo se implantasse de uma maneira muito mais lenta em Portugal do que nos outros paises europeus, seus vizinhos (a relaçäo dialética para a qual MARX chama a atençăo). Para isso contribuiu, também o fato de o Estado português ter se caracterizado como forte e centralizador e de em Portugal, não se ter desenvolvido a burguesia industrial - reflexo dos acordos económicos com a Inglaterra - fator imprescindivel para o desenvolvimento do capitalismo. (FAORO, 1978, v. 1)

Esses atributos do Estado português se transplantaram para a colónia brasileira através de um dos principais instrumentos da contra-reforma: a Companhia de Jesus, organizada em 1540, que utilizava para a "consecução de seus propósitos a pregaçăo, a confissăo e o ensino". (MONROE 1985, p. 183)

PAIVA (1985, p. 19), analisando o inlcio da ação pastoral jesultica em terras brasileiras (1549-1600) afirma que "a mensagem religiosa atendeu os objetivos da colonização" e chama a atençăo para o fato que, na época, não havia separação entre Igreja e Estado. A visão de mundo de ambos era um so: orbis christianus, fundado

8 - E interessante verificar a influencia comtista nas Escolas Militares a postura dos positivistas quanto ao voto, por exemplo. Isto permite compreender as atitudes dos militares quando no poder. (PAIM, 1967) 
"na crença de que o mundo e Deus, cujo representante na terra é a Igreja Católica. Este Deus, por ser verdadeiro, exigia que todos o reconhecessem e the prestassem culto. A verdade absoluta eis o princlpio e o fim do orbis christianus". (PAIVA, 1985, p. 22)

Aportuguesar, primeiro os indios, depois os filhos dos colonos, afigurava-se, para os jesultas, uma tarefa adequada à sua visāo de mundo.

Năo havia conflitos entre o Estado português e a ação dos jesultas; este conflito só foi ocorrer no séc. XVIII, quando o Marquês de Pombal pretendeu introduzir, em Portugal, as idéias liberais.

Até entăo os jesultas desenvolveram um ensino "completamente alheio à realidade da vida da Colónia. Desinteressado, destinado a dar cultural geral básica, sem a preocupaçāo de qualificar para o trabalho, uniforme e neutro, (...) não podia, por isso mesmo, contribuir para mudanças estruturais...". (ROMANELLI, 1983 p. 34)

Nem se pretendia isto. A finalidade do ensino, na época, na sua vertente humanista tradicional religiosa ${ }^{9}$. era a de educar segundo modelos pré-estabelecidos: modelos que traziam embutidos em sua natureza, a re'signação, a pobreza, a castidade, a submissāo às imposiçōes do destino, a lealdade, a tế inquebrantável em Deus. Ou seja, os modelos eram os Santos, os Mártires da Igreja, que haviam vivido uma vida terrena com os olhos voltados para o reino dos céus, lá onde todos serăo iguais e os humildes terão, afinal, a sua recompensa.

Em sintese, o que podemos inferir 6 que esse tipo de educação gerava conformismo, não possibilitando a busca da verdade que se encontrava nos fenómenos.

Tanto a vertente religiosa, como a leiga, do Humanismo Tradicional, estavam centradas na idéia de que o homem possui uma essência e que a finalidade da educaçăo era a de possibilitar que essa esséncia pudesse se manifestar plenamente.

Para a vertente religiosa, a esséncia do homem devia estar em conformidade com a de Deus, através da sua manifestaçăo humana - Cristo - ou, então, os santos, homens que haviam superado as fraquezas humanas $e$ se aproximado da natureza divina. A educação, portanto, devia preparar o homem para a eternidade.

A vertente leiga estava centrada na idéia de natureza humana mais de acordo com os valores da Reforma $e$ da burguesia. Sendo assim, seus modelos eram aqueles homens cuja vida merecia admiração e respeito.

Para ambas as vertentes, o professor era um mediador entre $O$ aluno e os modelos; $e 0$ ensino se centralizava em sua pessoa porque era ele quem dominava o conhecimento capaz de levar o aluno a atingir esse ideal educativo.

Essa concepçāo de mundo que năo procurava mudar a realidade existente fez com que o ensino fosse organizado de maneira a possibilitar a manutençāo do estado sócio-económico.
Nāo houve preocupaçāo com as escolas elementares; os filhos dos ricos possulam preceptores particulares, na maioria das vezes contratados no exterior; havia escolas médias para os homens da classe dominante e educaçāo superior religiosa. Quem quisesse se profissionalizar, necessitava ir para a Europa. França e Portugal foram os paises para os quais se dirigiu a populaçāo estudantil da época.

Foi depois de 1759, com a expulsão dos jesultas, e após um lapso de 13 anos que desmantelou completamente a estrutura administrativa do ensino, que os leigos adentraram o espaço escolar e o Estado assumiu os encargos educativos.

Lembremo-nos, no entanto, que a influência dos jesultas continuou através desses novos mestres. Pois não haviam sido eles educados nos colégios mantidos pela Ordem?

Os reflexos da situaçāo politica portuguesa se fizeram sentir com muita ênfase em terras brasileiras. As Reformas Pombalinas, influenciadas pelas idéias liberais, atingiram também o pensamento da intelectualidade brasileira, formada que era nas universidades portuguesa e francesa. As idéias liberais penetraram no Brasil, principalmente, através de duas correntes: o Ecletismo e o Positivismo.

Argumenta PAIM (1967) que o Ecletismo identificou-se profundamente com o esplrito nacional em processo de estruturação e consistia num amálgama dos elementos positivos das várias doutrinas que influenciavam a intelectualidade. Pretendia a conciliaçæ̌o dos elementos que compunham a sociedade brasileira com os anseios de modernizaçăo.

A corrente Ecletica predominou, entre 1830 e 1870, perlodo repleto de crises económicas e políticas, quando surgem as pressōes no sentido de abolir a escravidāo e tomam força as idéias republicanas.

O Manifesto Republicano, datado de 1870, é o mais vivo exemplo de que o Império estava estertorando.

Apesar de política e economicamente o Brasil estar passando por mudanças, estas aconteceram somente na superflcie. $O$ poder mudou de măos, mas năo de classe; portanto, a educaçăo - que sofre o reflexo da ideologia dominante - continuou e permaneceu, ate 1930, sob a influência das mesmas idéias pedagógicas: o humanismo tradicional, nas suas vertentes leiga e religiosa.

A maneira como fizemos o relato pode dar a impressåo que no universo educacional nảo havia questionamentos ou contestaçōes; que a populaçăo se subordinava aos ditames do poder hegemónico sem apresentar alternativas que demonstrassem haver outros caminhos que năo os oficiais.

Procuremos nos reportar aos anos iniciais da I República e obter uma panoråmica do que sucedia nos planos económico e polltico a fim de fazer uma ligaçăo com o educacional.

9 -. Estamos utillzando a classificaçăo de Damerval : Saviani expressa no texto Tendências e correntes da educaçáo brasileira lin MENDES lcoord.1, 1987, p. 19-47). Esta classificapjo compreende: concepç5o humanista tradicional, concepḉo humenista moderna, concepcto analfica e concepgtio dlalética. 
No plano económico, como já foi referido, iniciouse o processo de industrializaçăo.

Compreendamos, no entanto, essa indústria nascente como essencialmente articulada ao setor agrário: grande número de industriais eram advindos do campoaplicavam na indústria um capital excedente que, se aplicado no campo, traria riscos ou então nāo proporcionaria uma margem de lucro satisfatória.

Năo havia ruptura entre os dois capitais - o agrário e o industrial - ambos se articulavam com o intuito de resguardar interesses comuns. Esse pacto de coexisténcia se refletia no plano polftico na medida em que os indus: triais apoiavam os candidatos do setor agrário, nāo invadindo o espaço politico e estes, quando eleitos, aprova-. vam leis protecionistas às indústrias.

Mas o tecido social do infcio do século já nāo era aquele do século anterior: com a necessidade de suprir a falta de mão-de-obra, ocasionada pela aboliçăo da escravatura, incrementou-se uma política imigratória destinada a cumprir o papel até entāo desempenhado pelo elemento escravo. Coloriu-se de matizes o tecido social até então composto de poucas cores. $O$ imigrante não trouxe somente sua força de trabalho, junto com ela vieram também as idéias que vicejavam no continente europeu. Um continente que, no século $X I X$, presenciou a revolução industrial, a emergência do socialismo derivado das idéias de MARX e ENGELS, o desenvolvimento do sindicalismo, a presença do pensamento anarquista, contestando o poder instituldo e pregando a açāo direta como forma de luta.

Muitos dos imigrantes que aqui adentraram haviam participado ativamente do movimento operário europeu e, evidentemente, năo poderiam jamais, em identificando a situaçăo semi-escravagista de trabalho, permanecer insensiveis, calados, inoperantes.

Processaram-se, nesse perlodo, intensas lutas que colocaram no plano político a questão social - uma questāo que precisava ser resolvida para nāo continuar tumultuando o panorama.

FAORO (1987, p. 609) se reporta ao cuidado das elites em admitir as reivindicaçőes sociais e dar-lhes um rumo e cita Rui Barbosa "(Os Imigrantes) - Trouxe- ram ao Brasil, criaram no Brasil a questāo social. Ela urge conosco por medidas, que com seriedade atendam aos seus mais imperiosos reclamos".

Nota-se que do espanto inicial ocasionado pela surpresa ao se perceber a indocilidade do imigrante, passou-se para um processo de assimilação e acomodação através de leis que, se por um lado penalizavam o imigrante ${ }^{10}$, por outro procuravam regularizar as condiçōes de trabalho estabelecendo normas protetoras a mulher e à criança que participavam intensamente do trabalho fabril ${ }^{11}$.

Os industriais participaram ativamente nesta busca de atenuação do conflito procurando incutir no operariado valores que faziam parte do imaginário burgués e buscando controlar o seu modo de vida: lazer, moradia, relaçōes familiares, o papel da mulher e da criança, enfim todos os elementos do universo operário eram abarcados e se procurava moldá-los segundo a concepçāo burguesa.

Tudo precisava ser feito no inicio do século $X X$ : as condiçōes de saneamento eram péssimas; a febre amarela grassava afugentando turistas e colocando empeciIhos para a imigração; tanto a rede, como os meios de transporte eram precarlssimos; a dependência do mercado externo era total; 0 analfabetismo chegava ao alarmante e aviltante Indice de $80 \%$ (NAGLE, 1974 e PAIVA, 1973) e somado a tudo isso a necessidade de superar divergências internas ${ }^{12}$ para implantar um novo regime que, ao ser proclamado, já se tornou ditatorial.

Uma das maneiras de fortalecer a República, uma forma de governo que pressupōe a participaçăo do povo, era a de possibilitar essa participação. Como? Através do voto. De que maneira fazer isto se a própria Constituiçăo de 1891 negava aos analfabetos este direito ${ }^{13}$ Através das campanhas maciças de alfabetizaçäo. Criam-se, entăo, as Ligas Nacionais que văo perdendo impeto ao perceberem que o povo votante nem sempre vota segundo os interesses de quem o alfabetiza, como analisa NAGLE (1974.)

A escola do inicio do século é uma escola mal estruturada, mal gerenciada, parca em recursos humanos e financeiros e sem coerência em nivel nacional (não havia um sistema nacional que desse organicidade ao ensino).

10 . "... em janelro de 1907, o poder executivo do governo federal sancionou as duas resoluçóes decretadas pelo Congresso Nacional e relativas organlzaç̌o trabalhista. O Decreto 1637 exigia que os sindicatos depositassem em dia seus estatutos, em cartório acompanhados de uma lista de nomes dos membros da diretoria, só podendo fazer parte da mesma brasileiros natos où cidadáos naturalizados e residentes no pals há mais de cinco anos... O Decreto 1641 (a "lei Adolfo Gordo") regularizava a expulsão, de parte ou de todo o território nacional, dos estrangeiros que comprometessem a segurança nacional ou a tranquilidade pública...". (DULLES, 1977, p. 28-29)

11 - Essas leis apareceram em 1919 e 1923: o Código Sanitário de 1919 trazia medidas para proteger a mulher e a criança - proibia o trabalho para menores de 14 anos e o trabalho noturno para as mulheres. O Regulamento Nacional da Saúde Pủblica, de 1923 , fa* cilitava a licenca maternidade por 30 dias e fazia a proposta de lugares adequados para amamentaçăo, nos locais de trabalho. (AAGO, 1985)

12 - Essas divergéncias internas foram causadas pela uniáo que se tez necesséria a fim de se proclamar a República. Havia diversas tendenclas representadas no grupo responsával pela proclamação: a Escola de Guerra, por Benjamin Constant: a Armada, por Vandenkolk; a campanha republicena, por Quintino Aristides Lobo; a ala paulista, por Campos Sales; os rio-grandenses, pelo positivismo militante de Demótrio Ribeiro. "A composiçâo completa-se com Rui Barbosa defendendo o federalismo democrático e o chefe do Governo Provisório, Marechal Deodoro receoso de novidades". (REIS FILHO, 1981, p. 12)

13 - Este direito is se achava cerceado desde 19 de novembro de 1889, através do Decreto n 6. (Ibidem, p. 13) 
O sistema dual de ensino, herança do Império, permaneceu na Constituiçāo de 1891: enquanto à União coube a responsabilidade pelos ensinos superior e secundário, aos Estados delegou-se a responsabilidade pelos ensinos primb́rio e profissional.

Esse fato gerou uma situação caótica e um desnivel bastante acentuado entre os sistemas escolares dos diversos Estados, desniveis esses ocasionados pela diversidade económica dos mesmos 14 .

No perlodo da I República a populaçāo brasileira era eminentemente rural (somente após a década de 30 é que o processo de urbanização passaria a se acentuar) e a classe média, que principiava a emergir, era composta de intelectuais letrados, padres, militares, pequenos empresários e imigrantes que se ocupavam de profissōes tlpicas da classe média.

Pelo fato da maioria da população residir na zona rural e nāo sentir a educação como necessária, o governo pode ir atendendo a demanda pela escola: as vagas conseguiam suprir a procura.

Outro fato a ser levado em consideração é que a educaçāo literária e livresca, que havia sido caracteristica da Colónia e Império, permaneceu porque satisfazia aos interesses da classe dominante e porque estava de acordo com os anseios da população que tinha acesso à escola e via nela uma maneira de ascender socialmente. Para essa populaçāo, cultivar os valores que faziam parte do universo burguês era o mesmo que adquirir "status" social.

Para haver mudanças substanciais no panorama educacional, era necessário que a sociedade civil se organizasse para poder pressionar. Isto só irá acontecer no perlodo posterior à República quando o processo crescente de urbanizaçāo exigirá que se dêem novos rumos ao sistema educacional a fim de fazer frente a uma demanda cada vez maior.

Os embates polfticos que aconteciam durante a 1 República e que expressavam a disputa entre federalistas (liberais) e centralistas (positivistas) foi adquirindo contornos mais claros conforme se aproximava a decada de 30, que iniciou com a ascensảo de um lfder politico de formaçäo positivista: Getúlio Vargas.

Vargas assumiu a presidência em 1930 e nela se manteve ininterruptamente durante 15 anos. Foi alçado presidente na esteira de uma revolução e manteve-se no poder através de um discurso onde o apelo populista encobria o caráter repressivo e castrador do Estado. Como afirma NAGLE (1974, p. 5) " o Estado liberal brasileiro foi gradativamente se transformando no Estado repressivo, de tendência nitidamente policial".

A disputa entre federalismo e centralismo, que acontecia no nivel político, se refletiu no setor educacional ocasionando, como jâ foi referido, a divisăo de responsabilidade entre a Unižo e o Estado, em relação ao ensino.

O positivismo, por seu lado, fez com que se acen- tuassem a necessidade da instruçāo estendida às mulheres, a crença de que a educação constitula um dos pilares da afirmaçåo nacional, a laicidade do ensino, a gratuidade da escola primária e a necessidade de se fundamentar a formaçäo do educando na ciéncia, contestando a formaçẩo humanistica clássica. (RIBEIRO, 1982)

Os dois últimos aspectos: laicidade e gratuidade do ensino e fundamentaçāo do mesmo em bases cientlficas fizeram parte da reforma de Benjamin Constant, em 1890. Essa reforma foi bastante criticada por terem os currlculos apenas acrescentado matérias cientfficas às tradicionais, tornando o ensino enciclopédico. Além disso, nem chegou a ser posta em prática dada a falta de apoio das elites. (ROMANELLI, 1983)

Outras reformas aconteceram, mas näo chegaram a obter exito. Se limitaram a mexer na superflcie sem penetrar a fundo na questāo que originava os problemas, ou seja, a inadequação entre uma idéia pedagógica fundamentada em modelos educativos que não correspondia às necessidades e era voltada aos interesses das camadas médias e da elite, à uma sociedade que iniciava o processo de industrializaçẫo e adquiria uma configuração que destoava dos perlodos anteriores. Um novo modelo económico principiava a ser implantado, a nação brasileira estava com os olhos voltados para o futuro (sempre a naçāo do futuro!), mas as idéias pedagógicas permaneciam estagnadas, cristalizadas, apegadas ao passado: uma grande incoerência para um pals que pretendia acertar o passo com o ritmo da dança económica mundial.

Mas a sociedade brasileira não era constitulda somente pela elite e pela classe média, havia uma classe operária em formação que se organizava em sindicatos, uniōes, federaçöes e lutava por seus direitos.

Esse operariado influenciado pelas idéias socialistas - libertárias ou anarquistas; e comunistas -, cujo predominio variou conforme o século avançava, promovia reuniōes, publicava jornais e fundava escolas que tinham "um tipo de organização, que ao contrário das escolas públicas pode ser considerada de acordo com os interesses do grupo e a partir deles..." (WACHOWICZ, 1984, p. 10)

As idéias pedagógicas defendidas pelo pensamento para-oficial - em contraposiçāo ao oficial que imperava nas escolas públicas - encaravam a educação como fator de transformaçâo, mas sem delegar a ela poderes miraculosos, sem desvinculá-la dos outros elementos aos quais está essencialmente ligada e compreendendo-a como determinada historicamente. Divergindo, portanto, do pensamento liberal, pois para este a educaçăo era percebida e exercida como fator de manutençăo do estado sócio-económico e desvinculada das conjunçōes históricas.

Para os socialistas, havia uma estreita vinculaçäo

14 - ROMANELU (1983, p. 41), assim se refere ao analisar este fato "Era uma forma de oficializaçäo da distáncia que se mostrava, na

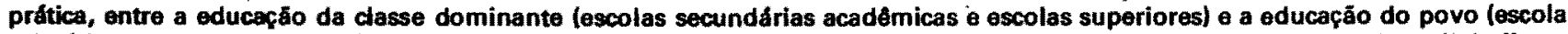
primária e escola profissionall. Refletia essa situação uma dualidade que era o próprio retrato da organizaçäo social brasileire". 
entre educação e política: a primeira como via de acesso para a segunda.

Os anarquistas, ou libertários, não empunhavam a bandeira da defesa do ensino público gratuito. Por serem frontalmente contrários a qualquer forma de poder instituido, nāo julgavam que coubesse ao Estado a tarefa de educar as massas. Cedo perceberam que as mensagens do ensino oficial tinham cunho ideológico e analisaram o professor como transmissor dessa ideologia.

Em termos de realizaçāo prática, fundaram, durante a I República, Centros de Estudos Sociais, Escolas e Universidades Populares de curta duração.

Os Centros de Estudos Sociais eram locais de educaçăo informal onde se difundia o ideário anarquista. Quanto à Escolas, ao invés de partirem para uma proposta autóctone, importaram as idéias primeiro de Robin - Educação Integral - depois de Ferrer - Ensino Racionalista.

"A idéia central contida na proposta de Educação Integral, ... era a da máxima importåncia a atividade e ao trabalho, pois o trabalho era encarado como o fundamental principio educativo". (GHIRALDELLI JR., 1987, p. 113)

Mais do que as idéias de Robin, foram as experiências de Ferrer, contemporâneo dos libertários brasileiros, que empolgaram o ideário pedagógico dos libertários nacionais e influenciaram a abertura de escolas nos moides das que existiam na Espanha.

Essas escolas, mantidas pelos trabalhadores e denominadas Modernas propunham uma pedagogia voltada para os interesses operários. Pedagogia esta fundada na razão, na ciência e na experimentaçăo e unindo o intelectual ao manual.

Contrariando os interesses das classes dominantes e enfrentando cerrada oposiçāo de setores da Igreja e do Estado, essas escolas tiveram enorme dificuldade para se manter e acabaram sendo fechadas na esteira de uma verdadeira caça aos anarquistas, muitos dos quais estavam sendo deportados sob a acusação de conspirarem contra o governo.

Depois do êxito da Revolução Russa, em 1917, e da expulsão de vários Ifderes anarquistas, os comunistas que, em 1922, fundaram o Partido Comunista Brasileiro, tiraram do primeiro plano do movimento operário, as idélas libertárias.

Partidários dà lúta parlamentar lao contrário dos anarquistas) incluiram na plataforma partidária um plano nacional de polltica educacional.

Esse plano inclula o ensino público obrigatório e gratuito, bandeira deixada de lado pelos libertários e empunhada pelos comunistas; o ensino profissional, entendido como continuaçăo natural e necessária da escola primária e năo como destinado aos desfavorecidos, como pretendia o governo; o resgate da funçảo e do trabalho do professor, entendendo o magistério como profissāo e năo sacerdócio.
"Enquanto os libertârios advogaram uma educação racionalista, cientificista e experimentalista, os comunistas pautaram-se pela educação polltico-partidária... o saber universal era pré-requisito para a militância revolucionária". (GHIRALDELLI JR., 1987, p. 152)

A luta parlamentar dos comunistas processava-se através dos BOC, Bloco Operário e Camponês, que os acobertava ${ }^{15}$. Através do BOC difundiam-se as idéias sobre a educação polf́lico-partidária; o plano pedagógico era discutido atravês de documentos internos do Partido, em âmbito bem mais restrito $e$ as idéias estavam de acordo com as das experiências educacionais que aconte ciam na Rússia.

\section{5 - CONCLUSÄO}

O presente trabalho desenvolveu-se no sentido de articular economia e politica para, através destes elementos, compreender a educaçāo de forma contextualizada.

Pelo exposto, evidenciou-se que a herança cultural do ideário pedagógico jesuita foi um fator que representou grande amarra no sentido de prender o pensamento pedagógico brasileiro d uma concepçăo essencialista de homem. O humanismo tradicional, nas suas vertentes religiosa e leiga, foi predominante até o final dos anos $20 \mathrm{e}$ se assim permaneceu é porque correspondia aos interesses da classe que dominava o pals polltica e economicamente, desde os tempos da Colónia.

No entanto, transpareceu também, com muita clareza, que, embora essa concepção pedagógica predominasse, o espaço educacional para-oficial era preenchido por outras idéias pedagógicas. Aquelas mesmas idéias que influenciavam o Movimento Operário europeu e se configuravam de acordo com a concepçăo dialética de educação, na medida em que entendiam que esta deveria partir dos interesses do grupo para o qual se destinava e a compreendiam como histórica e socialmente determinada.

Os socialistas - anarquistas e comunistas - viam na educação um instrumento de participação polltica, de questionamentos e não de adequação ao estabelecido, como pretendia o liberalismo.

Uma questāo se coloca: por que essas idéias pedagógicas, apesar de mais avançadas, foram deixadas de lado?

A resposta não se encontra no interior do pedagó. gico; ela deve ser buscada no politico. Na procura da recomposiçāo hegemónica de uma classe que via o seu projeto de sociedade ameaçado por forças que se afiguravam cada vez mais articuladas.

Relembremos o cenário brasileiro dos anos 20. Era um cenário bastante conturbado: a polftica dos governadores estava sendo colocada em xeque; as fraudes eleitorais abusivas causavam revolta; o constante revezamento da polftica do café com leite lora São Paulo, ora 
Minas Gerais) na chefia do governo estava desagradando os outros Estados que desejavam ter uma participação politica mais expressiva; o operariado agitava as grandes cidades com greves; a classe média estava insatisfeita querendo mudanças politicas e económicas que a favorecessem e clamava por mais escolas, continuando a enxergar na educação um instrumento de mobilidade social; militares se revoltavam e, além disto tudo, na longlnqua Rússia, uma revoluçāo operária havia sido vitoriosa.

Um novo mundo se prenunciava. Como lidar com todos esses fatores? Como permanecer se tudo clamava por mudança?

No plano político articulou-se uma Revoluçäo (a de 1930) que saiu vitoriosa colocou no poder um futuro ditador, dono de um discurso populista e que acabou esvaziando o Movimento Operário, através do trabalhismo, que cooptou as lideranças.

No plano económico, fortaleceu-se ainda mais o Capitalismo Industrial. Dado que a Europa havia enfrentado uma guerra de 1914 a 1918 , houve um favorecimento da indústria brasileira que se beneficiou com a interrupçāo da concorrência externa e com a abertura de alguns mercados de exportação. Nessa época, se consolidaram os grandes grupos empresariais e a burguesia industrial se fortaleceu, principiando a ocupar o espaço poIf́tico atê entāo exclusividade da oligarquia cafeeira.

No plano educacional, as idéias da Escola Nova, importadas da Europa e dos Estados Unidos e ligadas a uma interpretação psicológica do fenômeno educativo e nāo histórico-social como as do Movimento Operário, adentraram com todo impeto. A partir dos anos 20, essas idéias passaram a ser longamente debatidas e tomaram a forma de proposta no "Manifesto dos Pioneiros da Educação Nova", em 1932.

O Manifesto apresentou propostas de redirecionamento do ensino, fundamentadas na concepçăo humanista moderna, cuja visảo de homem está centrada na idéia de que a natureza humana é determinada pela existência e não pela essência, como pretendia a concepçăo humanista tradicional.

As idéias da Escola Nova representaram um avanço em termos do que se realizava na educaçăo oficial, mas, por outro lado, tiveram o mesmo efeito que o trabalhismo na śrea do Movimento Operário: impediram que a concepçāo dialética pudesse se firmar.

O educacional veio ao encontro do politico-econó- mico, permitindo que o sistema pudesse se recompor das vicissitudes a que havia sido submetido nos primeiros trinta anos do século e implantar definitivamente seu projeto de sociedade.

Nāo houve confronto entre as idéias do Movimento Operário e o trabalhismo; assim como não houve entre as idéias pedagógicas do operariado e o escolanovismo.

A cooptaçăo foi suave: deu-se a impressão, por parte do Estado, de que as reivindicaçōes estavam sendo atendidas. $E$ isso foi possivel porque tanto o trabalhismo. como o escolanovismo, encamparam muitos dos elementos que estavam presentes no ideário do operariado; só que lhes deram um outro direcionamento: aquele que interessava à classe hegemónica.

Permaneceram no Movimento da Escola Nova: a luta pelo ensino público, gratuito e obrigatório; a laicidade; a cientificidade dos conteúdos; a reivindicaçăo para que o Estado assumisse o controle da educação a fim de que esta pudesse ser única para todos, extinguindo os privilégios de classe. Por outro lado, o conteúdo politico da educação foi esvaziado. Colocou-se em seu lugar o plano psicológico como explicativo de todas as situaçōes.

A denúncia que os libertários já faziam da falta de neutralidade do professor e do comprometimento da escola com a ideologia do estado foi olvidada e, em seu lugar, se impós uma escola que se pretendia acima dos interesses de classe, como se isto fosse possivel.

Entre a concepção humanista tradicional e a concepção dialética de educaçăo, que conviviam lado a lado na I República, infiltrou-se a concepçảo humanista moderna, pretendendo superá-las e dar uma resposta às reivindicaçס̄es existentes.

E conseguiu. Conseguiu tảo bem que muitos anos foram necessários para que se pudesse começar a enxergar o engodo a que as classes subalternas haviam sido submetidas.

Trocou-se a quantidade pela pretensa qualidade; - Iógico pelo psicológico; o conteúdo pela forma e conseguiu-se esvaziar as reivindicaçర̄es, pela via da desqualificação da escola, do professor, do conteúdo, do aluno, enfim de todos os elementos que compóem o universo educacional formal.

A Escola Nova significou o fortalecimento de uma educação oficial ligada às elites e a recusa do Estado em se comprometer com o projeto social e politico das classes subalternas, que perfaziam (em) a maioria da populaçăo.

VALENTE, S.M.P. From colony period in Brazil to the first republic: a review of the pedagogical ideas. Semina: Ci.

Soc.JHum., Londrina, v. 13, n. 3; p. 195-207, Sept. 1992.

ABSTRACT: The analysis of the pedagogical ideas, since the Colony Period till the end of the First Republic, shows that politics and economy gathered to straighten the educational system. Also, shows that although these influences many came up ideas heading to release the system of the political tyranny. The research showed that there were two different educational projects in First Republic: the official inftueced by the jesuit's conception and the other presented by the socialists - anarchists and comunists - wich almed to answer the demand of the historical moment, when the work relations undergame by a deepchange. Both wore overcome by a thind project, the New School Project, which came up in the pedagogical world with conceptions imported from Europe and United States and made possible to the burguess wich were then threatned. 


\section{REFERÊNCIAS BIBLIOGRAFICAS}

AMTUNES, R,C. Oque sindicalismo: 14. ed. Sao Paulo: Brackitionse, 1988.

BASBAUN, L. Historia sincera da republica. 4. ed. Sto Paulo: Alta Omega, 1981, v. 2.

COVRE, M. de L.M. A tormaçáo e a ideologia do administrador de empresa 2. ed. Petrópolis: Vozes, 1982.

- A tala dos homens: an'tse do pensamento tecnocritico. Sto Paulo: Brastionse, 1988.

DECONLAL DO PENSAvENTO MARXSTA. Rio de Janelro: Zahar, 1803.

DULLES, J.W.F. Anarquistas e comunistas no Brasil (1900-1935). 2. ed. Rlo de Janciro: Nova Frontelra, 1977.

FAORO, R. Os donos do poder. 7. ed. Rlo de Janeiro: Globo, 1987. $\vee .1$ e 2 .

GHRALDELUJA, P. Educagáo a movimento operário. Sao Paulo: Corter, 1987.

CORZ, A. Ecologia y libertad: tócnica, tenlcos y lucha de chases. Barcelona: Editorial Gustavo Gil, 1979.

MUBERMAN, L. Historia da riqueza do homem 20. ed. Rlo de Janelro: Zahar, 1985.

JAGUARIBE, H. et al. Brasil 2000 Rlo de Janeiro: Paz e Terra, 1986.

MARX, K. OCapital: critce da economla poltica. 5. ed. Rlo de Janoiro: Chvilanglio Brastidra, 1980. Lrro 1, v. 1.

MAR, K. \& ENGELS, F. A idoologia alema. 5. ed. S4o Paulo: Huctuc, 1936.

MAX, D. ENCELS, F. Manilesto do partido comunista Putropolis: Voeed, 1988.

ILL, JMC. de Ocaptalismo tardia 7. ed. Sto Paulo: Bra-
MONROE, P. Histớia da educaçăo. 17. ed. Sao Paub: Ed. Nacional, 1985

NAGLE, J. Educaçăo e sociedade na primeira republica. Sso Paulo: Edusp, 1974.

PAM, A. Hisbria das idéias filosoficas no Brasil. Salo Paulo: GritalbolEdusp, 1967.

Parva, J.M. de. Colonizaçăo e catequese. Sfo Paulo: Cortez, 1935.

PAVA, V. Educaçáo popular e educaçdo de aduitos Sto Paulo: Loyola, 1973.

PRADO, M.C.A. Analfabelismo: o Brasil está plor que o Congo. Jornal Gazeta de Pinheiros, 16 out. 1988 , cad. A, p. 8.

RAGO, E.M. Do cabaré ao lar: a utopla da cidade disciplinar. Rlo de Janeiro: Paz e Terra, 1985.

REIS FILHO, C. dos. A educaçáo e a ilusảo liberal. Sáo Paulo: Cortez, 1981.

PIBERO, M.L.S. Históna da educaçăo brasileira: a organizaçăo escolar. 4. ed. Sio Paulo: Moraes, 1982.

ROMANELLI, O. DE O. Historia da educaçáo no Brasil (1930/1973). 4. ed. Petrópolls: Vozes, 1983.

SAVAN, D. Tendênclas e correntes da educaçåo brasileira. In: MENDES, D.T. Filosofia da educaçáo brasileira. 3. ed. Rlo de Janelro: Civillzaçáo Braslleira, 1987. p. $19-47$.

THOMPSON, C.P. Tradición, revuelta e consciéncia de clase (Estudios sobre la crisis de la sociedad preindustrial). Grijalbo: Editora Critica, 1979.

WACHOWCZ, L.A. Relaçáo prolessor - Estado no Paraná Tradicional Curltba: Cortez, 1984. 